\title{
Kajian pemalsuan bekatul dan tepung ikan di Wilayah Jawa Tengah
}

\author{
Cahya Setya Utama *, Bambang Sulistiyanto \\ Laboratorium Teknologi Pakan, Program Studi Peternakan, Departemen Peternakan, Fakultas Peternakan dan \\ Pertanian, Universitas Diponegoro, Semarang 50275 \\ *Correspondence: cahyasetyautama@gmail.com
}

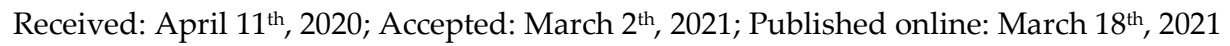

\section{Abstrak}

Tujuan: Penelitian bertujuan mengkaji pemalsuan kualitas bekatul dan tepung ikan yang berada di wilayah Jawa Tengah.

Metode: Materi yang digunakan yaitu bekatul dan tepung ikan yang berasal dari 17 wilayah di Jawa Tengah yang meliputi wilayah Rembang, Jepara, Batang, Solo, Boyolali, Pekalongan, Kendal, Temanggung, Magelang, Ungaran, Pati, Purwodadi, Demak, Salatiga, Kudus, Klaten dan Semarang. Metode penelitian menggunakan metode diskriptif kuantitatif. Pengambilan sampel dilakukan secara purposive random sampel untuk mewakili luasan wilayah yang dijadikan tempat penelitian (10 toko dalam 1 wilayah dengan membedakan kecamatan dan atau Desa). Pengukuran parameter pemalsuan pada bekatul menggunakan pengujian phloroglucinol, uji apung dan uji bulk density sedangkan tepung ikan menggunakan urea test.

Hasil: Hasil penelitian menunjukkan bahwa bekatul yang diuji phloroglucinol dan uji apung positif dipalsukan dengan menambah sekam dan terdapat pada wilayah Pati dan Demak. Uji bulk density menggambarkan bekatul yang memiliki bulk density tidak sesuai standar berada di wilayah Purwodadi, Kendal, Temanggung, Demak dan Semarang. Pemalsuan tepung ikan terjadi di wilayah pekalongan dan purwodadi dengan positif mengandung urea.

Kesimpulan: Kesimpulan penelitian adalah kualitas bekatul yang baik berdasarkan uji phloroglucinol, uji apung sekam dan uji bulk density ditemukan di wilayah Rembang, Jepara, Solo, Boyolali, Magelang, Ungaran, Salatiga dan Kudus sedangkan kualitas tepung ikan yang terindikasi pemalsuan berdasar urea test berada di wilayah Pekalongan dan Purwodadi.

Kata Kunci: Pemalsuan; Bekatul; Tepung ikan: Phloroglucinol; Urea test

\section{Abstract}

Objective: The research aimed examine the quality adulteration of bran and fish meal in the Central Java region.

Methods: The materials used are rice bran and fish meal originating from 17 regions in Central Java which include Rembang, Jepara, Batang, Solo, Boyolali, Pekalongan, Kendal, Temanggung, Magelang, Ungaran, Pati, Purwodadi, Demak, Salatiga, Kudus, Klaten and Semarang. The research method uses descriptive method. Sampling was carried out by purposive random sample to represent the area of the area used as the research site (10 shops in 1 region with different districts and / or villages). Measurement of the parameters of adulteration on bran used Phloroglucinol test, buoyancy test and specific gravity test, while fish meal used urea test. 
Results: The results showed that the bran which was tested for Phloroglucinol and positive buoyancy was faked by adding husks, and was found in the Pati and Demak areas. Density test describes rice bran with non-standard density in Purwodadi, Kendal, Temanggung, Demak and Semarang. Fish meal adulteration occurred in the Boyolali and Pati regions with positive urea content.

Conclusions: The conclusion of this research is that good quality of rice bran based on phloroglucinol test, husk floating test and bulk density test were found in Rembang, Jepara, Solo, Boyolali, Magelang, Ungaran, Salatiga and Kudus areas, the quality of fish meal indicated for adulteration based on the urea test was Pekalongan and Purwodadi areas.

Keywords: Adulteration; Rice Bran; Fish Meal; Phloroglucinol; Irea test

\section{PENDAHULUAN}

Peraturan Menteri Pertanian nomor: 65/ Permentan/OT.140/9/2007 tentang pedoman pengawasan mutu pakan, menegaskan pentingnya pakan berkualitas dan manajemen pengawasan mutu pakan yang dilakukan oleh Dinas terkait untuk menunjang ketersediaan pakan bermutu. Selain itu Undang-undang Nomor 18 Tahun 2009 tentang peternakan dan kesehatan hewan, pasal 21 menetapkan batasan tertinggi kandungan bahan pencemar fisik, kimia dan biologis pada pakan dan bahan pakan. Aturan tersebut digunakan untuk meminimalisasi tingkat pemalsuan, pencemaran dan menjamin kualitas bahan pakan dan pakan yang berada di pasaran, dengan harapan mampu meningkatkan produktivitas ternak. Sanksi yang diberikan pada pelanggar berupa sanksi administrasi maupun penutupan usaha yang dilakukan pada pelaku pemalsuan bahan pakan atau pengedar pakan dengan kandungan bahan tertentu yang dilarang oleh undang-undang.

Pakan memegang peranan terpenting dalam peningkatan produktivitas ternak. Pakan berkualitas terdiri dari campuran beberapa bahan pakan. Bahan pakan merupakan bahan yang dapat dimakan, dicerna, diabsorbsi dan bermanfaat bagi ternak [1]. Bahan pakan yang sering digunakan untuk menyusun ransum adalah jagung, bekatul, bungkil kedelai dan tepung ikan. Kualitas ransum dipengaruhi oleh kualitas bahan pakan. Jaminan mutu pakan perlu dilakukan pada setiap tahapan pembuatan pakan sehingga dapat meminimalisasi adanya pemalsuan bahan pakan. Pemalsuan bahan pakan menjadi masalah utama kualitas bahan pakan. Hal tersebut terkadang dilakukan oleh supplayer/ pedagang bahan pakan yang berharap keuntungan besar. Pemalsuan bahan pakan dilakukan dengan cara menambahkan bahan lain yang memiliki kriteria dan sifat fisik yang hampir sama dengan bahan aslinya [2-5].

Bekatul merupakan hasil ikutan dari penggilingan padi, yang terdiri dari selaput beras, menir dan sedikit sekam $(<5 \%)$ [6]. Ketersediaan bekatul yang melimpah pada musim panen, tidak diiringi dengan jaminan kualitas yang baik. Kualitas bekatul yang beragam, dapat dilihat dari tekstur, komposisi dan bau bekatul [7]. Bekatul dapat berperan sebagai pakan fungsional dan berpotensi sebagai prebiotik ternak [8, 9]. Pemalsuan bekatul biasanya ditambahkan dengan sekam dan pemalsuan tepung ikan biasanya ditambahkan dengan urea [10].

Tepung ikan terbuat dari daging ikan besar atau sisa-sisa ikan yang dikeringkan kemudian digiling sampai halus dan digunakan sebagai pakan sumber protein hewani bagi ternak [11]. Protein pada tepung ikan sangat penting untuk pertumbuhan, pemeliharaan organ tubuh, serta meningkatkan imunitas [12]. Akhadiarto [13] menyatakan bahwa tepung ikan merupakan bahan sumber protein hewani yang dibutuhkan ternak dan sulit digantikan oleh bahan pakan lain. Pemalsuan tepung ikan biasanya ditambahkan dengan urea, sehingga untuk mengetahui kualitas tepung ikan yang baik diperlukan urea test [10].

Sehubungan dengan hal tersebut, perlu dilakukan pengujian bahan pakan untuk menguji keaslian dan menghindari pembelian bahan pakan yang berkualitas buruk atau dipalsukan. Pengujian phloroglucinol, uji apung dan uji bulk density dilakukan untuk mengetahui pemalsuan pada bekatul 
sedangkan pengujian tepung ikan menggunakan urea test. Penelitian bertujuan mengkaji pemalsuan kualitas bekatul dan tepung ikan yang beredar di wilayah Jawa Tengah. Manfaat penelitian adalah memberikan informasi kepada masyarakat mengenai pemalsuan bekatul dan tepung ikan di wilayah Jawa Tengah. Penelitian sejenis tentang pengujian bahan pakan terutama bekatul dan tepung ikan sering dilakukan untuk kepentingan pengujian mutu bahan pakan pada perusahaan pakan dan dinas terkait pada wilayah tertentu. Penelitian ini memiliki kebaharuan dalam hal pengambilan sampel secara purposive random sampel dan pengambilan data secara langsung melalui observasi lapangan dan pengamatan secara langsung pada poultry shop (penjual bahan pakan) di 17 wilayah di Jawa Tengah dengan pertimbangan wilayah yang dirujuk merupakan sentra penghasil bekatul dan tepung ikan.

\section{MATERI DAN METODE}

Materi yang digunakan dalam penelitian ini adalah bekatul dan tepung ikan yang diambil dari 17 wilayah yang ada di Jawa Tengah.

Penelitian menggunakan metode diskriptif kuantitatif, dimana data yang diperoleh diukur dan dibuat dalam bentuk tabel terstruktur. Penelitian diawali dengan membeli bekatul dan tepung ikan sebanyak $1 \mathrm{~kg}$ pada 17 wilayah yang ada di Jawa Tengah secara purposive random sampel [14]. Pemilihan 17 Wilayah didasarkan pada ketersediaan dan kontinuitas bahan yang diteliti di wilayah tersebut. Pengambilan sampel penelitian dilakukan secara purposive random sampel untuk mewakili luasan wilayah yang dijadikan tempat penelitian (10 toko dalam 1 wilayah dengan membedakan kecamatan dan atau desa). Pemilihan 10 toko dalam 1 wilayah didasarkan pada banyak sedikitnya penjualan akan bahan yang akan diteliti. Wilayah yang dimaksud adalah Rembang, Jepara, Batang, Solo, Boyolali, Pekalongan, Kendal, Temanggung, Magelang, Ungaran, Pati, Purwodadi, Demak, Salatiga, Kudus, Klaten dan Semarang. Bekatul yang dijadikan sampel penelitian sudah bisa dipastikan jenis bekatul, bukan dedak halus atau dedak kasar dengan cara dilakukan pengamatan secara organoleptis pada saat pembelian dengan harga berkisar Rp. 3.000,sampai Rp. 4.500,- per kg. Tepung ikan yang dijadikan sampel penelitian merupakan tepung ikan lokal dengan harga dipasaran berkisar antara Rp. 12.500 sampai Rp. 20.000,per kg.

\section{Prosedur Penelitian}

Pengujian pemalsuan bekatul meliputi uji phloroglucinol, uji apung dan uji bulk density dan pengujian tepung ikan menggunakan urea test.

Pengujian Phloroglucinol. Pengujian phloroglucinol dilakukan dengan cara memasukkan sampel pada petridish kemudian ditambahkan larutan phloroglucinol 1\% sebanyak 5 tetes. Jika timbul bercak merah maka bekatul dipalsukan dengan sekam dan apabila terdapat buih maka bekatul dipalsukan menggunakan tepung batu [13].

Uji Apung Sekam. Pengujian ini diawali dengan memasukkan aquades ke dalam beaker glass sampai 3/4 permukaan, kemudian ditambahkan 5 gram bekatul dan diamati selama 15 menit. Jika terdapat partikel yang mengapung, diduga bekatul dipalsukan menggunakan sekam [13].

Uji Bulk Density. Uji bulk density dilakukan dengan cara menimbang gelas ukur, kemudian bekatul dimasukkan kedalam gelas ukur sampai tidak terdapat rongga selanjutnya ditimbang kembali. Perhitungan bulk density bekatul menggunakan persamaan dengan rumus [4]:

$$
\text { Bulk Density }=\frac{\text { Berat sampel }}{\text { Volume wadah }}
$$

Densitas bekatul secara normal berkisar $0,35-0,40 \mathrm{~g} / \mathrm{ml}$. Jika densitas di atas normal maka mengindikasikan bekatul dipalsukan dengan tepung batu/kapur, jika di bawah normal mengindikasikan bekatul dipalsukan menggunakan sekam [4].

Urea Test. Urea test terdiri dari 3 tahapan yaitu pembuatan ekstrak urease, pembuatan urea test paper dan pengujian sampel. Pembuatan ekstrak urease dilakukan dengan menggiling kedelai mentah hingga halus 
(diayak atau disaring) kemudian bubuk kedelai diambil sebanyak 50 gram lalu dicampur dengan $200 \mathrm{ml}$ air aquades, diadukaduk hingga merata setelah itu didiamkan selama 24 jam, setelah itu ekstrak urease disaring.

Pembuatan urea test paper dilakukan dengan mencampurkan $10 \mathrm{ml}$ ekstrak urease dicampur dengan $10 \mathrm{ml}$ larutan indikator (BTB). Setelah tercampur kertas saring (Whatman no.41) dicelupkan dalam larutan tersebut hingga tercelup merata di seluruh permukaan kertas. Kertas saring dikeringkan dengan cara diangin-anginkan atau dipanaskan. Kertas saring yang sudah kering akan berwarna kuning orange ketika kering.

Urea test dilakukan dengan cara urea test paper diletakkan kedalam petridish lalu larutan urea standar diteteskan pada urea test paper. Tepung ikan dengan ukuran 20 mash diletakkan di atas urea test paper kemudian ditetesi aquades dan diamati perubahan warna yang terjadi, jika terjadi perubahan warna menjadi biru mengindikasikan tepung ikan dipalsukan dengan menambahkan urea [13].

\section{Analisis Data}

Pengolahan data dilakukan dengan menggunakan metode diskriptif kuantitatif. Data hasil penelitian disusun dalam tabel yang merupakan susunan data, kemudian diinterpretasikan sesuai dengan hasil pengamatan yang ada $[14,15]$.

\section{HASIL}

Hasil penelitian mengenai kajian pemalsuan bekatul dan tepung ikan di wilayah Jawa Tengah disajikan dalam Tabel 1.

\section{Uji Phloroglucinol pada Bekatul}

Berdasarkan hasil penelitian didapatkan pada 15 wilayah tidak ditemukan pemalsuan sedangkan 2 wilayah terdapat pemalsuan bekatul (Tabel 1). Hasil uji phloroglucinol menggambarkan wilayah Demak dan Pati terdapat pemalsuan sekam. Pengujian phloroglucinol yang positif mengindikasikan bahwa adanya pemalsuan penambahan sekam di dalam bekatul. Larutan phloroglucinol adalah larutan pendeteksi unsur lignin. Kandungan sekam yang ditolerir dalam bekatul maksimal 5\%. Kadar maksimal 5\% diukur dari luasan petridish yang digunakan dalam pengujian bekatul menggunakan larutan phloroglucinol.

\section{Uji Apung Sekam pada Bekatul}

Hasil penelitian (Tabel 1) menunjukkan bahwa, 15 wilayah tidak ditemukan pemalsuan dan 2 wilayah terjadi pemalsuan. Wilayah tersebut yaitu Pati dan Demak. Uji apung mengindikasikan banyaknya partikel yang mengapung. Partikel yang terapung tersebut diindikasi sebagai sekam. Semakin banyak partikel yang mengapung maka kualitas bekatul semakin jelek. Hal ini mengindikasikan bahwa partikel tersebut tidak dapat dicerna oleh saluran pencernaan dan bersifat voluminous sehingga menyebabkan bulky. Bahan yang bulky menyebabkan sistem pencernaan ternak tidak maksimal dan menurunkan produktivitas ternak.

\section{Uji Bulk Density (Berat Jenis) pada Bekatul}

Pengujian bulk density bekatul bertujuan mengetahui kepadatan dari bekatul. Jika densitas di atas normal maka mengindikasikan bekatul dipalsukan dengan tepung batu/kapur dan jika di bawah normal mengindikasikan bekatul dipalsukan menggunakan sekam. Tabel 1 menggambarkan bahwa beberapa wilayah di Jawa Tengah terindikasi memiliki densitas di bawah standar seperti wilayah Kendal, Temanggung, Purwodadi, Demak dan Semarang, sedangkan yang memiliki densitas diatas normal adalah wilayah Batang, Pekalongan, Pati dan Klaten.

\section{Urea Test pada Tepung Ikan}

Hasil penelitian pada Tabel 1 menunjukkan bahwa terjadi pemalsuan tepung ikan di wilayah Pekalongan dan Purwodadi. Hasil urea test menggambarkan bahwa tepung ikan mengandung urea. Penambahan urea pada tepung ikan bertujuan memalsukan kadar protein pada tepung ikan. Hal ini terjadi dikarenakan urea merupakan non protein nitrogen (NPN), sehingga dalam analisis protein akan meningkatkan kandungan protein bahan pakan. 
Tabel 1. Hasil Pengujian Phloroglucinol, Uji Apung, Bulk Density dan Urea Test

\begin{tabular}{clcccc}
\hline No. & Kabupaten & Uji Phloroglucinol & Uji Apung & Bulk Density $(\mathrm{g} / \mathrm{ml})$ & Urea Test \\
\hline 1. & Rembang & Negatif & Negatif & $0,39 \pm 0,01$ & Negatif \\
2. & Jepara & Negatif & Negatif & $0,36 \pm 0,02$ & Negatif \\
3. & Batang & Negatif & Negatif & $0,47 \pm 0,07^{*}$ & Negatif \\
4. & Solo & Negatif & Negatif & $0,39 \pm 0,03$ & Negatif \\
5. & Boyolali & Negatif & Negatif & $0,39 \pm 0,01$ & Negatif \\
6. & Pekalongan & Negatif & Negatif & $0,43 \pm 0,08^{*}$ & Positif \\
7. & Kendal & Negatif & Negatif & $0,33 \pm 0,01^{*}$ & Negatif \\
8. & Temanggung & Negatif & Negatif & $0,32 \pm 0,01^{*}$ & Negatif \\
9. & Magelang & Negatif & Negatif & $0,39 \pm 0,09$ & Negatif \\
10. & Ungaran & Negatif & Negatif & $0,35 \pm 0,01$ & Negatif \\
11. & Pati & Positif & Positif & $0,41 \pm 0,03^{*}$ & Negatif \\
12. & Purwodadi & Negatif & Negatif & $0,34 \pm 0,01^{*}$ & Positif \\
13. & Demak & Positif & Positif & $0,31 \pm 0,01^{*}$ & Negatif \\
14. & Salatiga & Negatif & Negatif & $0,36 \pm 0,01$ & Negatif \\
15. & Kudus & Negatif & Negatif & $0,39 \pm 0,02$ & Negatif \\
16. & Klaten & Negatif & Negatif & $0,49 \pm 0,05^{*}$ & Negatif \\
17. & Semarang & Negatif & Negatif & $0,31 \pm 0,01^{*}$ & Negatif \\
\hline
\end{tabular}

Keterangan : Sampel tiap kabupaten diambil dari 10 lokasi toko bahan pakan yang berbeda. ${ }^{*}$ Tidak memenuhi nilai densitas normal bekatul, densitas normal bekatul sebesar 0,35 - 0,40 g/ml [13]

\section{PEMBAHASAN}

\section{Uji Phloroglucinol pada Bekatul}

Berdasarkan Tabel 1 menunjukkan bahwa kualitas bekatul pada berbagai wilayah yang ditinjau dari uji phloroglucinol memiliki kualitas yang cukup baik kecuali bekatul yang berasal dari wilayah Pati dan Demak. Hal ini ditunjukkan dengan uji phloroglucinol positif terdapat bercak merah. Unsur lignin adalah unsur utama yang terdapat pada sekam. Larutan phloroglucinol berfungsi sebagai penampak bercak merah pada bekatul yang telah dipalsukan menggunakan sekam. Hal ini sesuai dengan pendapat Hartati et al. [16] yang menyatakan bahwa keberadaan lignin dapat diketahui secara kualitatif dengan menggunakan pewarnaan phloroglucinol- $\mathrm{HCl}$ $1 \%$, dan larutan tersebut akan menyebabkan perubahan warna menjadi merah. Lignin akan bereaksi dengan larutan phloroglucinol asam dan berubah warna menjadi merah, semakin banyak warna merah maka bahan yang diuji menandakan semakin banyak kandungan lignin dan termasuk kedalam bahan yang kurang baik. Phloroglucinol dapat dipakai untuk mengetahui kualitas bekatul yang baik berdasarkan kadar serat kasarnya, mulai 5\%, $10 \%, 15 \%, 20 \%$ dan $25 \%$. Uji ini paling cepat dilakukan hanya dalam waktu $15-20$ menit.
Dengan demikian para peternak tidak bisa ditipu oleh penjual bekatul dengan pencampuran sekam giling dan/atau tepung batu kapur [17]. Patiwiri [18] menyatakan bahwa keberagaman dedak padi disebabkan oleh varietas padi, penggilingan dan pemalsuan seperti penambahan sekam giling, serbuk gergaji, tepung tongkol, jagung, dan tepung kulit kacang.

\section{Uji Apung Sekam pada Bekatul}

Kualitas bekatul pada berbagai wilayah di Jawa Tengah ditinjau dari uji apung sekam sudah cukup baik kecuali bekatul yang berasal dari wilayah Pati dan Demak (Tabel 1). Berdasarkan Uji apung, bekatul yang berasal dari wilayah tersebut terindikasi pemalsuan menggunakan sekam. Hal ini sesuai dengan pendapat Kushartono [10] yang menyatakan bahwa bekatul yang dipalsukan menggunakan sekam ketika diuji menggunakan uji apung akan terdapat banyak sekam yang terapung. Semakin banyak partikel yang terapung maka, semakin buruk kualitas bekatul. Partikel yang terapung pada uji apung adalah sekam, bulk density sekam lebih kecil jika dibandingkan dengan bulk density bekatul sehingga sekam akan terapung [1]. Ini sesuai dengan pendapat Telew et al. [19] yang menyatakan bahwa 
kandungan nutrisi dalam sekam relatif rendah, dapat menyebabkan gangguan pencernaan pada ternak. Partikel yang tersuspensi dalam uji apung adalah sekam, gravitasi spesifik sekam lebih kecil jika dibandingkan dengan gravitasi spesifik air sehingga sekam akan mengambang. Botahala [20] menyatakan bahwa bulk density sekam lebih kecil dari bulk density air, hal ini akan menyebabkan sekam mengapung. Makin banyak sekam yang mengapung, makin jelek kualitas dedak padi $[17,21]$.

\section{Uji Bulk Density (Berat Jenis) pada Bekatul}

Hasil penelitian yang disajikan pada Tabel 1 menunjukkan bahwa kualitas bekatul pada berbagai wilayah di Jawa Tengah ditinjau dari uji bulk density terdapat beberapa wilayah yang tidak sesuai dengan standar bulk density bekatul yaitu $0,35-0,40 \mathrm{~g} / \mathrm{ml}$ [13]. Singh et al. [22] yang menyatakan bahwa kepadatan curah bekatul umumnya berkisar antara $0,35 \mathrm{~g} / \mathrm{ml}$.

Bekatul yang memiliki bulk density yang berada di bawah standar $(<0,35 \mathrm{~g} / \mathrm{ml})$ berasal dari wilayah Purwodadi, Kendal, Temanggung, Demak dan Semarang, sedangkan bekatul yang memiliki bulk density di atas standar berasal dari Batang, Pekalongan, Pati dan Klaten. Bulk density yang lebih kecil dan lebih besar dari standar mengindikasikan bahwa terdapat pemalsuan pada bahan pakan. Nilai bulk density yang tidak sesuai dengan standar baik itu lebih kecil ataupun lebih besar mengartikan bahwa suatu bahan pakan tersebut mengalami kontaminasi atau pemalsuan dengan bahan yang lain. Jika densitas di atas normal maka mengindikasikan bekatul dipalsukan dengan tepung batu/kapur dan jika di bawah normal mengindikasikan bekatul dipalsukan menggunakan sekam [4]. Faktor-faktor yang memengaruhi bulk density adalah kepadatan dan ukuran partikel bahan pakan. Hal ini sesuai dengan pendapat Listyani dan Zubaidah [23] yang menyatakan bahwa kepadatan dan ukuran bahan pakan merupakan faktor yang dapat menentukan besarnya bulk density. Amrullah [24] menyatakan bahwa bulk density akan meningkatkan jumlah ransum yang dapat ditampung dalam tembolok per satuan waktu. Bulk density juga sangat menentukan tingkat ketelitian dalam proses penakaran seperti proses pengemasan dan proses pengeluaran bahan dari silo untuk dicampur [25].

\section{Urea Test pada Tepung Ikan}

Kualitas tepung ikan pada berbagai wilayah di Jawa Tengah ditinjau dari uji urea test sudah cukup baik kecuali tepung ikan yang berasal dari wilayah Boyolali dan Pati. Wilayah tersebut tepung ikannya positif mengandung urea. Pemalsuan menggunakan urea diketahui dari perubahan warna pada urea test paper menjadi warna biru. Perubahan warna biru disebabkan oleh enzim urease memecah nitrogen dan ikatan karbon yang kemudian membentuk ammonia dan akan menyebabkan lingkungan menjadi alkali sehingga $\mathrm{pH}$ basa kemudian akan terjadi perubahan warna menjadi biru [26]. Hal ini sesuai dengan pendapat Huda et al., [27] yang menyatakan bahwa urease adalah enzim yang dapat memecah nitrogen dan ikatan karbon dalam senyawa amida kemudian membentuk ammonia sehingga menyebabkan lingkungan menjadi alkali dan $\mathrm{pH}$ basa kemudian terjadilah perubahan warna menjadi biru. Zusfahair et al. [28] menyatakan bahwa tes urea dilakukan untuk mendeteksi keberadaan urea dalam suatu material. Pemalsuan menggunakan urea telah diketahui dari perubahan warna pada kertas urea test menjadi biru. Orlan et al. [29] menyatakan bahwa tepung ikan yang bermutu baik harus mempunyai sifat-sifat seperti butiran halus, seragam, bebas dari sisa tulang, mata ikan dan benda asing, warna halus bersih, serta bau khas amis ikan.

\section{KESIMPULAN}

Kesimpulan dari penelitian adalah kualitas bekatul yang baik berdasarkan uji phloroglucinol, uji apung dan uji bulk density ditemukan di wilayah Rembang, Jepara, Solo, Boyolali, Magelang, Ungaran, Salatiga dan Kudus sedangkan kualitas tepung ikan yang terindikasi pemalsuan berdasar urea test berada di wilayah Pekalongan dan Purwodadi. 


\section{KONFLIK KEPENTINGAN}

Penulis menyatakan penelitian ini tidak bersinggungan dengan peneliti lainnya dan tidak ada konfik kepentingan dengan setiap hubungan keuangan, pribadi, maupun instansi terkait materi yang dibahas di dalam naskah ini.

\section{REFERENSI}

1. Subekti, E. 2009. Ketahanan pakan ternak indonesia. J. Mediagro. 5(2): 63 - 71. Doi: 10.31942/md.v5i2.562

2. Schneider, B. H., and P. F. William. 1975. The evaluation of feeds through digestibility experiments. Athens (Grece): The University of Georgia Pr.

3. Saunders R. M. 1985. Rice bran: composition and potential food sources. Food Rev. Inter. 1(3):465-495. Doi: 10.1080/ 87559128509540780

4. Khalil. 1999a. Pengaruh kandungan air dan ukuran partikel terhadap sifat fisik pakan lokal: kerapatan tumpukan, kerapatan pemadatan tumpukan dan berat jenis. Media Peternakan. 22 (1): $1-11$.

5. Giger, R. S. 2000. Characterization of feedstuffs for ruminants using some physical parameters. Anim. Feed Sci. Tech. 86:53-69. Doi: 10.1016/S0377-8401(00)001 59-0

6. Astawan M dan E. F. Andi. 2010. Potensi dedak dan bekatul beras sebagai ingredient pangan dan produk pangan fungsional. J. Ilmu Pangan 19(1): 16-18. Doi:10.33964/jp.v19i1.104

7. Sukria, H. A dan K. Rantan. 2009. Sumber dan Ketersediaan Bahan Baku Pakan di Indonesia. Bogor (ID): IPB Press

8. Astawan, M dan A. E. Febrinda. 2010. Potensi dedak dan bekatul beras sebagai ingredient pangan dan produk pangan fungsional. J. Pangan 19(1):14-21. Doi: 10.33964/jp.v19i1.104

9. Tuarita, M. Z., N. F. Sadeka, Sukarno, N. D. Yuliana, dan S. Budijanto 2017. Pengembangan bekatul sebagai pangan fungsional: peluang, hambatan, dan tantangan. J. Pangan. 26(2): 167-176. Doi: 10.33964/jp.v26i2.354
10. Hartadi, S., S. Reksodihadiprodjo, A. D. Tillman. 1997. Tabel Komposisi Pakan untuk Indonesia, UGM Press, Yogyakarta.

11. Kushartono, B. 2000. Penentuan kualitas bahan baku pakan dengan cara organoleptik. Balai Penelitian Ternak, Temu Ternak Fungsional non Peneliti. pp. $217-223$.

12. Nento, W. R., dan P. S. Ibrahim. 2017. Analisa kualitas nugget ikan tuna (Thunnus sp.) selama penyimpanan beku. J. Agr. Sci. 1(2): 75-81. Doi: 10.30869/ jasc.v1i2.134

13. Akhadiarto, S. 2015. Prospek pembuatan pakan ayam dari bahan baku lokal (contoh kasus gorontalo). J. Sains dan Teknologi Indonesia 17(1):7-15. Doi: 10.29122/jsti. v17i1.3420

14. Sugiyono. 2010. Metode Penelitian Bisnis (pendekatan kuantitatif, kualitatif dan R\&D). Penerbit CV. Alfabeta. Bandung.

15. Sudjana. 2002. Metoda Statistika. Penerbit Tarsito. Bandung.

16. Hartati, N. S., E. Sudarmonowati., Suharsono dan K. Sofiyani. 2011. Analisis kuantitatif dan uji histokimia lignin sengon (Paraserianthes falcataria). Widyariset. 14(3): $525-534$.

17. Standar Nasional Indonesia. 2001. Dedak padi / Bahan Baku Pakan No 01-3178-1996. Jakarta (ID): Dewan Standardisasi Nasional Indonesia.

18. Patiwiri AW. 2006. Teknologi Penggilingan Padi. PT. Jakarta (ID): Gramedia Pustaka Utama

19. Telew, C., V. G. Kereh, I. M. Untu dan B. W. Rembet. 2013. Pengayaan nilai nutritif sekam padi berbasis bioteknologi "effective microorganisms" (EM4) sebagai bahan pakan organik. J. Zootec. 32 (5): 1 8. Doi: 10.35792/zot.32.5.2013.983

20. Botahala, L. 2019. Perbandingan Efektivitas Daya Adsorpsi Sekam Padi Dan Cangkang Kemiri Terhadap Logam Besi (Fe) Pada Air Sumur Gali. Pendidikan Deepublish, Yogyakarta.

21. Khalil, 1999b. Pengaruh kandungan air dan ukuran partikel terhadap sifat fisik pakan lokal: sudut tumpukan, daya ambang dan faktor higroskopis. Media Peternakan 22(1): 33-42. 
22. Singh, K. K., R. Rastogi, S. H. Hasan. 2005. Removal of Cr (VI) from wastewater using rice bran. J. of Colloid and Interface Sci. 290: 61 - 68. Doi: 10.1016/j.jcis.2005.04.011

23. Listiyani, A. dan E. Zubaidah. 2015. Formulasi opak bekatul padi (kajian penambahan bekatul dan proporsi tepung ketan putih: terigu). J. Pangan dan Agro Industri. 3(3): 950 - 956.

24. Amrullah I K. 2003. Nutrisi Ayam Petelur. Bogor (ID): Lembaga Satu Gunung Budi.

25. Geldart, D. M., F. Mallet and N. Rolfe. 1990. Assesing the flowability of powder using angle of repose powder. Handling and Processing 2(4): 341 - 345.

26. Lawa, E. D. W. dan E. J. L. Lazarus. 2015. Suplementasi tepung ikan terproteksi ekstrak tanin hijauan kabesak kuning, kabesak hitam dan kihujan dalam ransum terhadap pertumbuhan ternak kambing.
J. Zootek. 35 (2):368-378. Doi: 10.35792/ zot.35.2.2015.9456

27. Huda, C., Salni dan Melki. 2012. Penapisan aktivitas antibakteri dari bakteri yang berasosiasi dengan karang lunak Sarcophyton sp. Maspari Journal. 4(1) : 69 76. Doi:10.36706/maspari.v4i1.1343

28. Zusfahair, D. R. Ningsih., A. Fatoni dan D. S. Pertiwi. 2018. Pemurnian Parsial dan Karakterisasi Urease dari Biji Kacang Panjang (Vigna unguiculata subsp sesquipedalis L.). Alchemy J. Penelitian Kimia. 14 (1): 72 - 83. Doi: 10.20961/alchemy.14.1.13000.72-83

29. Orlan, N. S. Asminaya dan F. Nasiu. 2019. Karakteristik fisiko kimia tepung ikan yang diberi pengawet bawang putih (allium sativum) pada masa penyimpanan yang berbeda. J. Agripet : 19(1): 68-76. Doi:10.17969/agripet.v19i1.14147 